\title{
The Australian Dollar and Gold Prices
}

\author{
Nicholas Apergis ${ }^{*}, 1$ and Dimitrios Papoulakos ${ }^{2}$ \\ ${ }^{I}$ Department of Banking \& Financial Management, University of Piraeus, Greece \\ ${ }^{2}$ Saxo Bank, Greece
}

\begin{abstract}
This paper explores the association between the nominal/real exchange rate between the Australian dollar against the US dollar and gold prices, using daily data spanning the period 2000-2011. Through the Error Correction Model and the Generalized Autoregressive Heteroskedastic (GARCH) approach, the empirical findings provide evidence in favor of a relationship between the exchange rate and gold prices, in terms of both means and conditional volatilities. The results are important, in terms of information availability, for monetary policymakers, hedge funds managers and international portfolio managers. Moreover, they provide additional support to the hypothesis that both markets are driven by the same information set.
\end{abstract}

JEL Classification: F31, Q11, C22.

Keywords: Gold prices, Australian dollar/US dollar exchange rate, error correction model, GARCH model.

\section{INTRODUCTION AND LITERATURE}

Both the breakdown of the Bretton Woods System on August 15, 1971 and the adoption of the regime of the freely floating exchange rates have generated an increasing interest in the examination of the relationship between currency exchange rates movements and economic parameters such as supply, demand, interest rates, economic growth, inflation rates and other macroeconomic fundamentals (Sercu and Uppal [1]). The relationship between economic parameters and exchange rates has been one of the most controversial issues in international economics and a long-standing puzzle.

On the first hand, Meese and Rogoff [2] are the first who show that it is virtually impossible to explain or predict nominal exchange rates using standard macroeconomic models and fundamental variables to short term periods, though they find that accuracy generally increases at longer periods, while they demonstrate that a variety of linear structural exchange rate models fails to forecast more accurately than a naive random walk model for both real and nominal exchange rates. Frankel and Rose [3] conclude with doubts about the value of time series modeling of exchange rates at high or medium frequencies using macroeconomic models and summarize the various difficulties in the empirically relating exchange rate behavior to shocks in macroeconomic fundamentals.

More importantly, in two seminal papers, Frankel [4] and Frankel and Saike [5] argue that the recent case of Argentina has motivated many scholars and users of the international exchange market to give extra thoughts whether for countries specialized, in terms of production and exports, in certain

*Address correspondence to this author at the Department of Banking \& Financial Management, University of Piraeus, Greece;

Tel: +302104142429; Fax: +302104142341; E-mail: napergis@unipi.gr commodities was most relevant to fixes the local-currency prices of those extra commodities (the Peg the Export PricePEP hypothesis). This particular option offers adequate antiinflation credibility in the implementation of domestic monetary policy, while it would simultaneously sterilize their commodity markets and their terms of trade from excessive fluctuations (volatility) in the international value of their currencies. In other words, the PEP hypothesis offers both an adjustment to trade shocks and a nominal anchor.

For Canada, Australia and New Zealand, countries that depend heavily on commodity exports, the world price of commodities appears to have a strong and systematic relationship to their currencies (Chen and Rogoff [6]). Chen [7] extends his work to look at commodity-price augmented monetary models for nominal exchange rate determination and out-of-sample forecasts. He finds that the inclusion of a commodity price term can improve the forecast performance of standard models dramatically. It has long been observed that there is a close relationship between the price of some primary commodities such as gold, oil, agricultural products and certain currencies, described as 'commodity currencies', with a large share of production and exports accounted by primary commodities as those described before. The main idea behind 'commodity currencies' is that the value of a commodity currency usually rises or falls in relation with the value of the country's main commodity exports. Both the value of a commodity and the country's trade balance are significant factors in the valuation of commodity currencies. The most commonly traded 'commodity currencies' are those of the Canadian dollar, the New Zealand dollar and the Australian dollar. These three countries are highly integrated into global capital markets and are active participants in international trade. Chen et al. [8] investigate the behavior of the exchange rate for the currencies of Australia, Canada, Chile, New Zealand and South Africa with respect to the US 
dollar, i.e. countries where commodities account for a large portion of exports. Their study finds that exchange rates help predict world commodity prices.

Since 1983 the Australian dollar (AUD) has been floated, while core reforms, i.e. the development of an active local bond market and a non-deliverable forward currency market, led to the 'internationalization' of the currency and to a substantial rising of the living standards of Australians. This floating exchange rate regime acted as a buffer to external shocks, i.e. shifts in the terms of trade. This regime allowed the economy to absorb such shocks without the associated inflation changes that characterized the previous managed floating regime. Today, the AUD is the sixth most traded currency globally, while the exchange rate between the AUD and the USD is the fourth most traded currency pair.

Commodity terms of trade have recently attracted renewed interest due to their wild fluctuations. Indeed, commodity prices are generally found to drive exchange rate fluctuations in commodity-exporting countries (Chen and Rogoff [6]; Cashin et al. [9]), while econometric models of equilibrium exchange rates often include this series among their explanatory variables (Isard [10]; Ricci et al. [11]).

It has been also contended that movements in Australia's exchange rates are influenced substantially by changes in the country's terms of trade. This view has been corroborated by the work of Blundell-Wignall and Gregory [12] and Gruen and Wilkinson [13] who both establish a long-run relationship between Australia's exchange rates and the country's terms of trade. This should be of interest to all those countries whose currencies seem to be susceptible to terms-of-trade shocks. The list of such countries includes not only small, open, commodity-exporting countries like Australia, Canada, and New Zealand, but also the U.S., Japan, and Germany, whose terms of trade are shocked negatively by rises in international oil prices.

Australia is a major exporter of mining and agricultural commodities and there has long been a close relationship between commodity prices and the AUD. Commodity prices, at least in the medium-term, affect the value of the AUD due to Australia's dependence on mining and farming exports. When world commodity prices rise, the AUD appreciates and vice versa. Since commodities account for a significant component of Australia's exports, while, commodities maintained a $60 \%$ share of Australia's total exports, this close link between commodity prices and the AUD is also reflected as a close relationship between Australia's terms of trade and the real exchange rate. Blundell-Wignall and Gregory [12], Blundell-Wignall et al. [14] and Gruen and Wilkinson [13] argue that the terms of trade are a fundamental determinant of the real exchange rate for a commodity exporting country, following the vast literature studying the impact of exchange rate volatility on trade flows. Sercu and Uppal [1] conclude that even in a very simple model it is possible to have either a negative or a positive relationship between trade and exchange rate volatility, depending on the source underlying the increase in exchange rate volatility. Moreover, Chen et al. [8] support that price fluctuations in world commodity markets represent exogenous terms-of-trade shocks that impact a significant share of the country' exports.

After coal, iron ore, and crude petroleum, gold currently ranks fourth in value of all Australia's merchandise exports. There is perhaps no other industrial endeavor that has had such a profound effect on the Australian nation as gold, economically and socially. Australia has had a productive and vibrant gold industry for over 150 years, while the extent of economic gold resources has always been a difficult issue to quantify the fluctuations of international gold prices and their association with the value of the AUD.

Following an International Monetary Fund (IMF) meeting on August 15, 1971, the price of gold was allowed to float. On that time there was also the perception in the Australia industry that gold investments were risky. However, the increase in world gold prices to more than USD500 an ounce by the early 1980s and the widespread acceptance of exploration techniques, led to a rapid increase in gold production. It is true that gold in many cases has been characterized as 'safe haven' for investors seeking protection from falling stock prices (Baur and Lucey [15]). In other words, the presence of gold is likely to enhance the stability and resiliency of the financial system, because it dampens negative shocks falling on various assets (Baryshevsky [16]; Capie et al. [17]). But gold has historically been more than just a safe haven. It has also played a vital role in the monetary system as real money. The demand for gold has recently surged as investors have turned to the precious metal to protect their investments against global uncertainty and as a way to hedge against inflationary concerns. The metal's price is up a stunning 619 percent (at 2011) since its low in 1999, while the S\&P 500 index is down 16 percent. Therefore, fluctuations of international gold prices are crucial for the value of the Australian dollar.

The primary goal of this empirical paper is to examine, for the first time, the strength of the association between gold prices in Australia, a heavily gold-exporting country, and the nominal/real exchange rate of the Australian dollar (with respect to the US dollar), both in terms of means and volatilities. Once foreign exchange traders know whether gold is strongly correlated with the idiosyncratic characteristics of its production and exports, they can better predict how gold prices could affect the exchange rate under investigation.

This paper contributes to the relevant literature by focusing on investigating, for the first time, the dynamic relationship between nominal and real exchange rate changes and gold prices in Australia. The paper provides more evidence about the implications of the association between the two variables under investigation in terms of currency risk hedging. According to Chen and Rogoff [6] approach, the empirical results are expected to offer a substantial insight to policymakers, on the grounds that: i) there is a great concern in the literature about whether policymakers in small open economies should respond to exchange rate movements when setting domestic monetary policy (Brischetto and Voss [18]; Dungey and Pagan [19]) and ii) the results would be of particular interest to foreign 
exchange traders, hedge funds managers and international portfolio managers, where trading among currencies requires the examination of the relationship between different markets to capitalize on gold investments.

The paper is organized as follows. Section 2 comprises the empirical implementation of the study, including a description of the data and the econometric results, while Section 3 reports robustness empirical test results. Finally, section 4 summarizes the results and concludes.

\section{EMPIRICAL ANALYSIS}

\subsection{Data}

Daily data on gold prices (GP) and the Australian dollar/US dollar exchange rate (AUD) were obtained from Bloomberg spanning the period 2000-2011. For the purposes of the empirical analysis, demeaned continuously compounding percentage returns of gold prices and the exchange rate are computed by taking the daily difference of the natural logarithms, subtracting the sample mean and multiplying by 100 . Gold prices are US closing spot gold, published in the New York COMEX as Cash Gold Prices, converted into Australian dollars.

The empirical analysis will also be implemented with respect to the real exchange rate (RER). To this end, monthly data on domestic and US prices (proxied by CPI indices) were obtained from Datastream, on long-term real interest rates (proxied by the 10-year bond rates) were obtained from Datastream, while those on the terms of trade (TT) were obtained from International Financial Statistics. Real interest rates were calculated as the difference between nominal interest rates and actual inflation. Throughout the paper, lower-case letters, except for the case of long-term real interest rates, signify variables in natural logarithms, while the RATS software (Version 7.0) assisted the empirical analysis.

\subsection{Integration Analysis}

We test for unit root non-stationarity by using the Dickey and Fuller [20] test. In particular, the analysis is based on the augmented Dickey-Fuller unit root test, the results of which are presented in Table 1. Using a 5 per cent significance level, these data clearly accept the hypothesis of a unit root for both series in levels. When first differences were used, unit root non-stationarity was rejected in both cases.

KPSS tests proposed by Kwiatkowski et al. [21] are also employed. These tests (also shown in Table 1) are applied with a trend in their levels and without a trend in their first differences. The literature typically follows this approach for the level test to check for trend stationarity and for the firstdifference test to check for stationarity around a level. The KPSS results are reported using 0,2, 4, and 8 lags. Once again, the hypothesis of a unit root is not rejected for all variables under study at the 1 per cent level. When first differences are used, unit root non-stationarity is rejected.

\subsection{Modelling Mean Processes for Gold Prices and the AU Dollar/US Dollar Exchange Rate}

In this section, the analysis identifies both the gold prices and the AU dollar/US dollar exchange rate processes. A gold prices-AU dollar/US dollar exchange rate system consists of the following Error Correction (EC) equations:

Table 1. Unit Root Tests

\begin{tabular}{|c|c|c|c|c|c|c|c|c|}
\hline \multicolumn{9}{|l|}{ ADF Tests } \\
\hline \multicolumn{9}{|l|}{ Variable } \\
\hline \multirow{2}{*}{\multicolumn{2}{|c|}{$(\mathrm{X})$}} & \multicolumn{3}{|c|}{ Levels } & \multicolumn{4}{|c|}{ First Differences } \\
\hline & & \multicolumn{2}{|l|}{ Without Trend } & With Trend & \multicolumn{2}{|r|}{ Without Trend } & \multicolumn{2}{|c|}{ With Trend } \\
\hline \multicolumn{2}{|l|}{ gp } & \multicolumn{2}{|l|}{$-1.36(6)$} & $-1.68(6)$ & \multicolumn{2}{|r|}{$-6.24(5)^{*}$} & \multicolumn{2}{|c|}{$-6.48(5)^{*}$} \\
\hline \multicolumn{2}{|l|}{ aud } & \multicolumn{2}{|l|}{$-1.28(6)$} & $-1.84(6)$ & \multicolumn{2}{|r|}{$-7.74(5)^{*}$} & \multicolumn{2}{|c|}{$-9.35(5)^{*}$} \\
\hline \multicolumn{2}{|l|}{ rer } & \multicolumn{2}{|l|}{$-1.41(5)$} & $-1.71(5)$ & \multicolumn{2}{|r|}{$-5.83(4)^{*}$} & \multicolumn{2}{|c|}{$-6.43(4)^{*}$} \\
\hline \multicolumn{2}{|l|}{$\mathrm{tt}$} & \multicolumn{2}{|l|}{$-1.26(5)$} & $-1.53(5)$ & \multicolumn{2}{|r|}{$-4.97(4)^{*}$} & \multicolumn{2}{|c|}{$-5.74(4)^{*}$} \\
\hline \multicolumn{2}{|l|}{ dri } & \multicolumn{2}{|l|}{$-4.94(5)^{*}$} & $-5.64(5)^{*}$ & & & & \\
\hline \multicolumn{9}{|l|}{ KPSS Tests } \\
\hline \multirow{2}{*}{ Variables, Lags } & \multicolumn{4}{|c|}{ Levels-with Trend } & \multicolumn{4}{|c|}{ First Differences-with Trend } \\
\hline & $\mathbf{0}$ & 2 & 4 & 8 & $\mathbf{0}$ & 2 & 4 & 8 \\
\hline gp & 1.38 & 1.19 & 0.99 & 0.65 & $0.15 \#$ & $0.14 \#$ & $0.11 \#$ & $0.07 \#$ \\
\hline aud & 2.05 & 1.35 & 1.12 & 0.41 & $0.24 \#$ & $0.15 \#$ & $0.09 \#$ & $0.02 \#$ \\
\hline rer & 1.66 & 1.43 & 1.18 & 0.61 & $0.29 \#$ & $0.18 \#$ & $0.11 \#$ & $0.06 \#$ \\
\hline $\mathrm{tt}$ & 1.42 & 1.26 & 1.06 & 0.58 & $0.26 \#$ & $0.15 \#$ & $0.09 \#$ & $0.04 \#$ \\
\hline dri & $0.26 \#$ & $0.18 \#$ & $0.10 \#$ & $0.05 \#$ & & & & \\
\hline
\end{tabular}

Numbers in square brackets denote the optimal number of lags used in the augmentation of the test regression and are obtained through the Akaike criterion *Indicates that the unit root null hypothesis is rejected at the 5 per cent level; \# accepts the null hypothesis of stationarity at the 5 per cent level. 


$$
\begin{gathered}
\Delta \mathrm{gp}_{\mathrm{t}}=\mathrm{a}_{10}+\sum_{\mathrm{i}=1}^{5} \mathrm{a}_{1 \mathrm{i}} \Delta \mathrm{gp}_{\mathrm{t}-\mathrm{i}}+\sum_{\mathrm{i}=1}^{5} \mathrm{a}_{2 \mathrm{i}} \Delta \operatorname{aud}_{\mathrm{t}-\mathrm{i}}+\mathrm{b}_{1} \mathrm{EC}_{\mathrm{t}-1}+\mathrm{u}_{1 \mathrm{t}} \\
\Delta \operatorname{aud}_{\mathrm{t}}=\mathrm{a}_{20}+\sum_{\mathrm{i}=1}^{5} \mathrm{a}_{3 \mathrm{i}} \Delta \mathrm{gp}_{\mathrm{t}-\mathrm{i}}+\sum_{\mathrm{i}=1}^{5} \mathrm{a}_{4 \mathrm{i}} \Delta \operatorname{aud}_{\mathrm{t}-\mathrm{i}}+\mathrm{b}_{1} \mathrm{EC}_{\mathrm{t}-1}+\mathrm{u}_{2 \mathrm{t}}
\end{gathered}
$$

with EC being the cointegration residuals, while $\mathrm{u}_{1 \mathrm{t}}$ and $\mathrm{u}_{2 \mathrm{t}}$ denote both error terms. Finally, $\mathrm{a}_{10}$ and $\mathrm{a}_{20}$ are constants, whilst $\mathrm{a}_{\mathrm{is}}$ are the coefficients of explanatory variables.

Next, Johansen and Juselius [22] cointegration tests are performed. They reveal evidence in favor of cointegration between gold prices and the AU dollar/US dollar exchange rate. The cointegration results are reported in Table $\mathbf{2}$. Both the eigenvalue test statistic and the trace test statistic indicate that there is a single long-run relationship among the variables under study. Once the presence of a cointegrating relationship is established, an associated all-encompassing EC system, which describes the short-run dynamics, is also considered. This specification models the mean equations for gold prices and the AU dollar/US dollar exchange rate.

Table 2. Cointegration Tests

\begin{tabular}{|c|c|c|c|c|c|}
\hline \multicolumn{6}{|l|}{ Lags $=\mathbf{6}$} \\
\hline $\mathbf{r}$ & $\mathbf{n}-\mathbf{r}$ & $\mathbf{m l}$ & $\mathbf{9 5}$ Per Cent & $\mathbf{T r}$ & $\mathbf{9 5}$ Per Cent \\
\hline \hline $\mathrm{r}=0$ & $\mathrm{r}=1$ & 64.6895 & 29.0000 & 72.3671 & 51.3500 \\
\hline $\mathrm{r}<=1$ & $\mathrm{r}=2$ & 1.3348 & 10.4400 & 1.3348 & 10.4400 \\
\hline
\end{tabular}

$\mathrm{r}$ is the number of cointegrating vectors, $\mathrm{n}-\mathrm{r}$ is the number of common trends, $\mathrm{ml}=$ maximum eigenvalue statistic, $\operatorname{Tr}=$ Trace statistic. The number of lags is determined through Likelihood Ratio tests, developed by Sims [23].

Normalizing the cointegration vector on the nominal exchange rate, we obtain the following estimates:

$$
\begin{aligned}
\text { aud }= & 1.583-0.598 \mathrm{gp} \\
& (7.81)^{*}(-7.37)^{*}
\end{aligned}
$$

$\mathrm{R}$-squared $=0.58 \quad \mathrm{LM}=1.34[0.37] \quad \mathrm{RESET}=1.26[0.40]$

Numbers in parentheses denote t-statistics, while an asterisk denotes significance at the $1 \%$ statistical level. LM and RESET are tests for serial correlation and model functional misspecification, respectively, while figures in brackets denote p-values. The coefficient on gold prices is correctly signed and statistically significant. It shows that a one percent increase in gold prices leads to an appreciation of the exchange rate by virtually 0.60 percent.

Table 3 reports the results from the EC system. Looking at the models' overall performance, the estimated equations satisfy certain econometric criteria, namely, absence of serial correlation (LM test) and absence of model functional misspecification (RESET test). ARCH tests are also applied to test the residual structure in the mean equations. The results reject the hypothesis of independent errors in both equations. In other words, significant ARCH effects appear

\begin{tabular}{|c|c|c|}
\hline Coefficient & Gold Prices & $\begin{array}{l}\text { AU Dollar/US Dollar } \\
\text { Exchange Rate }\end{array}$ \\
\hline$a_{10}$ & $0.0362(1.45)$ & \\
\hline$a_{11}$ & $0.318(7.49)^{*}$ & \\
\hline$a_{12}$ & $0.168(5.68)^{*}$ & \\
\hline$a_{13}$ & $0.116(5.21)^{*}$ & \\
\hline $\mathrm{a}_{14}$ & $0.102(5.17)^{*}$ & \\
\hline$a_{15}$ & $0.074(4.88)^{*}$ & \\
\hline$a_{21}$ & $0.168(8.71)^{*}$ & \\
\hline $\mathrm{a}_{22}$ & $0.122(6.13)^{*}$ & \\
\hline$a_{23}$ & $0.105(5.35)^{*}$ & \\
\hline$a_{24}$ & $0.084(5.09)^{*}$ & \\
\hline$a_{25}$ & $0.037(4.77)^{*}$ & \\
\hline$b_{1}$ & $-0.158(-6.74)^{*}$ & \\
\hline $\mathrm{a}_{20}$ & & $0.0562(1.27)$ \\
\hline$a_{31}$ & & $-0.311(-5.18)^{*}$ \\
\hline $\mathrm{a}_{32}$ & & $-0.162(-4.85)^{*}$ \\
\hline $\mathrm{a}_{33}$ & & $-0.125(-5.06)^{*}$ \\
\hline $\mathrm{a}_{34}$ & & $-0.116(-4.65)^{*}$ \\
\hline$a_{35}$ & & $-0.084(-4.57)^{*}$ \\
\hline $\mathrm{a}_{41}$ & & $0.274(6.14)^{*}$ \\
\hline$a_{42}$ & & $0.218(5.38)^{*}$ \\
\hline$a_{43}$ & & $0.131(4.82)^{*}$ \\
\hline$a_{44}$ & & $0.105(4.62)^{*}$ \\
\hline $\mathrm{a}_{45}$ & & $0.053(4.39)^{*}$ \\
\hline $\mathrm{b}_{2}$ & & $-0.284(-6.27)^{*}$ \\
\hline \multicolumn{3}{|c|}{ Diagnostic Statistics } \\
\hline $\mathbf{R}^{2}$ & 0.56 & 0.52 \\
\hline LM & $2.14[0.24]$ & $2.19[0.34]$ \\
\hline RESET & $1.35[0.23]$ & $1.67[0.49]$ \\
\hline $\mathrm{ARCH}(1)$ & $6.71[0.00]$ & $7.66[0.00]$ \\
\hline $\mathrm{ARCH}(4)$ & $6.44[0.00]$ & $5.82[0.00]$ \\
\hline $\mathrm{ARCH}(8)$ & $5.83[0.00]$ & $5.14[0.00]$ \\
\hline $\mathrm{ARCH}(12)$ & $5.35[0.00]$ & $6.59[0.00]$ \\
\hline
\end{tabular}
to be present in both mean processes and the hypothesis of time-varying conditional variance is applied.

Table 3. Error Correction Model Estimates 


\subsection{Conditional Volatility Estimates: Spillover Effects Between Gold Prices Volatility and the AU Dollar/US Dollar Exchange Rate Volatility}

A GARCH model is considered as a parsimonious special case of an ARMA process applied to the squared stochastic error term, as discussed in Engle and Kroner [24] and Lee [25]. A Box-Jenkins selection procedure indicates that a GARCH $(1,1)$ model exhibits the best fit. Higher lags in the GARCH specification are also employed, but they are found to be statistically insignificant. The following GARCH model is used:

$$
\Delta \mathrm{gp}_{\mathrm{t}}=\mathrm{a}_{10}+\sum_{\mathrm{i}=1}^{5} \mathrm{a}_{1 \mathrm{i}} \Delta \mathrm{gp}_{\mathrm{t}-\mathrm{i}}+\sum_{\mathrm{i}=1}^{5} \mathrm{a}_{2 \mathrm{i}} \Delta \mathrm{aud}_{\mathrm{t}-\mathrm{i}}+\mathrm{b}_{1} \mathrm{EC}_{\mathrm{t}-1}+\mathrm{u}_{1 \mathrm{t}}
$$$$
\Delta \operatorname{aud}_{\mathrm{t}}=\mathrm{a}_{20}+\sum_{\mathrm{i}=1}^{5} \mathrm{a}_{3 \mathrm{i}} \Delta \mathrm{gp}_{\mathrm{t}-\mathrm{i}}+\sum_{\mathrm{i}=1}^{5} \mathrm{a}_{4 \mathrm{i}} \Delta \mathrm{aud}_{\mathrm{t}-\mathrm{i}}+\mathrm{b}_{1} \mathrm{EC}_{\mathrm{t}-1}+\mathrm{u}_{2 \mathrm{t}}
$$

and

$$
\begin{aligned}
& \mathrm{h}_{\mathrm{t}}^{\mathrm{gp}}=\mathrm{d}_{1}+\mathrm{d}_{2} \mathrm{u}_{1(\mathrm{t}-1)}{ }^{2}+\mathrm{d}_{3} \mathrm{~h}_{\mathrm{t}-1}^{\mathrm{gp}}+\mathrm{d}_{4} \mathrm{~h}_{\mathrm{t}-1}^{\text {aud }} \\
& \mathrm{h}_{\mathrm{t}}^{\text {aud }}=\mathrm{d}_{5}+\mathrm{d}_{6} \mathrm{u}_{2(\mathrm{t}-1)}{ }^{2}+\mathrm{d}_{7} \mathrm{~h}_{\mathrm{t}-1}^{\mathrm{gp}}+\mathrm{d}_{8} \mathrm{~h}_{\mathrm{t}-1}^{\text {aud }}
\end{aligned}
$$

where $\mathrm{u}_{1 \mathrm{t}}$ and $\mathrm{u}_{2 \mathrm{t}}$ are stochastic disturbance terms of the mean processes for gold prices and the AU dollar/US dollar exchange rate, respectively, and EC is the error correction term. Finally, $h_{t}{ }^{g p}$ and $h_{t}$ aud are the conditional variances of gold prices and the AU dollar/US dollar exchange rate, respectively. Maximum likelihood techniques, proposed by Bollerslev and Wooldridge [24], are used to estimate heteroskedasticity-consistent parameter estimates of the GARCH model. The empirical results on conditional estimates for the variables under consideration are reported in Table 4. Numbers in parentheses are robust t-statistics in order to allow for possible violations of the assumption of normality (Bollerslev and Wooldridge [26]).

Table 4 also illustrates the results of several diagnostic tests for the GARCH model specification. The statistics show that the Bollerslev's [27] LM test rejects model's misspecification. The diagnostic statistics also strongly support the GARCH $(1,1)$ model as a reasonably good description of the stochastic behavior of the conditional volatility of gold prices and the AU dollar/US dollar exchange rate. In addition, constancy tests are reported for the estimated equations. The statistic implies acceptance of the null hypothesis of parameter constancy. Ljung-Box statistics of the standardized and the squared standardized residuals are all insignificant. Finally, the $\mathrm{TR}^{2}$ statistic provides robustness support for the absence of time-varying variance.

The diagonal elements $d_{3}$ and $d_{8}$ reflect the level of persistence in the conditional variances. The results show that the coefficient estimates for the lagged variance terms are statistically significant at the one percent significance level. The off-diagonal parameter $\mathrm{d}_{3,8}$ captures the extent to which the conditional variances of gold prices and the AU dollar/US dollar exchange rate are correlated with their lagged conditional variances. The estimate is shown to be statistically significant at 1 per cent, indicating the presence of a gold prices-AU dollar/US dollar exchange rate volatility

\begin{tabular}{|c|c|c|}
\hline $\mathrm{d}_{3}$ & \multicolumn{2}{|c|}{$0.516(9.62)^{*}$} \\
\hline $\mathrm{d}_{8}$ & \multicolumn{2}{|c|}{$0.427(7.35)^{*}$} \\
\hline $\mathrm{d}_{3,8}$ & \multicolumn{2}{|c|}{$0.168(5.48)^{*}$} \\
\hline $\mathrm{d}_{2}$ & \multicolumn{2}{|c|}{$0.255(5.71)^{*}$} \\
\hline $\mathrm{d}_{6}$ & \multicolumn{2}{|c|}{$0.284(5.56)^{*}$} \\
\hline $\mathrm{d}_{2,6}$ & \multicolumn{2}{|c|}{$0.083(5.61)^{*}$} \\
\hline $\mathrm{d}_{4}$ & \multicolumn{2}{|c|}{$0.184(6.63)^{*}$} \\
\hline $\mathrm{d}_{7}$ & \multicolumn{2}{|c|}{$0.288(6.19)^{*}$} \\
\hline $\mathrm{d}_{4,7}$ & \multicolumn{2}{|c|}{$0.216(6.51)^{*}$} \\
\hline \multicolumn{3}{|c|}{ Diagnostic Statistics } \\
\hline $\mathrm{L}(\mathrm{Q})$ & \multicolumn{2}{|c|}{4557.18} \\
\hline $\mathrm{LM}_{1}$ & \multicolumn{2}{|c|}{$1.25[0.32]$} \\
\hline $\mathrm{LM}_{2}$ & \multicolumn{2}{|c|}{$1.47[0.35]$} \\
\hline \multirow[t]{2}{*}{$\mathrm{LM}_{3}$} & \multicolumn{2}{|c|}{$1.61[0.37]$} \\
\hline & $\Delta$ gp & $\Delta$ aud \\
\hline $\mathrm{Q}(1)$ & $0.91[0.60]$ & $0.91[0.58]$ \\
\hline $\mathrm{Q}(4)$ & $1.14[0.47]$ & $1.24[0.61]$ \\
\hline$Q^{2}(1)$ & $1.53[0.29]$ & $1.44[0.40]$ \\
\hline$Q^{2}(4)$ & $1.33[0.31]$ & $1.72[0.35]$ \\
\hline $\mathrm{TR}^{2}$ & $1.46[0.24]$ & $1.27[0.36]$ \\
\hline Bollerslev's LM Test & & \\
\hline & $0.41[0.30]$ & $0.24[0.43]$ \\
\hline
\end{tabular}
trade-off.

Table 4. Conditional Volatility Estimates

$d_{i}$ shows diagonal estimates, while $d_{i, j}$ shows off-diagonal estimates. Numbers in parentheses denote absolute quasi-maximum likelihood t-statistics developed by Bollerslev and Wooldridge [26], while those in brackets denote p-values; L(Q) is the function value. $\mathrm{LM}_{1}, \mathrm{LM}_{2}$ and $\mathrm{LM}_{3}$ are constancy tests for the GARCH models. $\mathrm{Q}$ and $\mathrm{Q}^{2}$ denote the Ljung-Box test for residual serial correlation and ARCH effects, while $\mathrm{TR}^{2}$ denotes the test statistic for ARCH effects.

*Significant at 1 percent level.

The parameters $d_{2}$ and $d_{6}$ reveal the extent to which the conditional variances of gold prices and the AU dollar/US dollar exchange rate are correlated with past squared innovations, i.e. the residuals from their mean model. The off-diagonal element $\mathrm{d}_{2,6}$ depicts how the conditional variances of gold prices and the AU dollar/US dollar exchange rate is correlated with the past squared innovation of these variables. The estimate is statistically significant at 1 per cent, lending support to the presence of a cross-effect. 
The parameters $d_{4}$ and $d_{7}$ capture the effects of the lagged term of those conditional variances on gold prices and the AU dollar/US dollar exchange rate. These diagonal elements are statistical significant at the 1 per cent level. Concentrating on the equation for gold prices, the estimates reveal that the AU dollar/US dollar exchange rate volatility coefficient is positive, indicating that the lagged exchange rate conditional variance raises the conditional volatility of gold prices. In other words, the conditional volatility of the exchange rate incorporates certain informational contents for gold prices. Such empirical findings provide support to the Meese-Rogoff [2] literature about the capacity of the exchange rate volatility to explain future movements in the volatility of commodity prices. Current levels of conditional variables are shown to be statistically insignificant at various conventional significance levels.

\subsection{Causality Effects}

Finally, to examine causal relationships among the variables under study, a vector autoregressive model (VAR) is estimated. In particular, the following dynamic $4 \times 4$ (VAR) model is estimated:

$$
\begin{aligned}
& \Delta_{\mathrm{t}}^{\mathrm{gp}}=\mathrm{a}_{30}+\sum_{\mathrm{i}=1}^{4} \mathrm{a}_{\mathrm{li}} \Delta \mathrm{gp}_{\mathrm{ti}}+\sum_{\mathrm{i}=1}^{4} \mathrm{a}_{2 \mathrm{i}} \Delta \operatorname{aud}_{\mathrm{ti}}+\sum_{\mathrm{i}=1}^{4} \mathrm{~b}_{3 \mathrm{i}} \mathrm{h}_{\mathrm{ti}}^{\text {gp }}+\sum_{\mathrm{i}=1}^{4} \mathrm{~b}_{4 \mathrm{i}} \mathrm{h}_{\mathrm{ti}}^{\text {aud }}+\varepsilon_{\mathrm{lt}} \\
& \Delta_{\mathrm{t}}^{\text {aud }}=\mathrm{a}_{40}+\sum_{\mathrm{i}=1}^{4} \mathrm{a}_{3 \mathrm{i}} \Delta \mathrm{gp}_{\mathrm{ti}}+\sum_{\mathrm{i}=1}^{4} \mathrm{a}_{4 \mathrm{i}} \Delta \operatorname{aud}_{\mathrm{ti}}+\sum_{\mathrm{i}=1}^{4} \mathrm{~b}_{5 \mathrm{i}} \mathrm{h}_{\mathrm{ti}}^{\mathrm{gp}}+\sum_{\mathrm{i}=1}^{4} \mathrm{~b}_{6 \mathrm{i}} \mathrm{h}_{\mathrm{ti}}^{\text {aud }}+\varepsilon_{2 \mathrm{t}} \\
& \mathrm{h}_{\mathrm{t}}^{\mathrm{gp}}=\mathrm{a}_{50}+\sum_{\mathrm{i}=1}^{4} \mathrm{a}_{5 \mathrm{i}} \Delta \mathrm{gp}_{\mathrm{ti}}+\sum_{\mathrm{i}=1}^{4} \mathrm{a}_{6 \mathrm{i}} \Delta \mathrm{aud}_{\mathrm{ti}}+\sum_{\mathrm{i}=1}^{4} \mathrm{~b}_{\mathrm{z}_{\mathrm{i}} \mathrm{h}_{\mathrm{t} \mathrm{i}}{ }^{\mathrm{gp}}}+\sum_{\mathrm{i}=1}^{4} \mathrm{~b}_{8 \mathrm{i}} \mathrm{h}_{\mathrm{ti}}^{\text {aud }}+\varepsilon_{3 \mathrm{t}}
\end{aligned}
$$

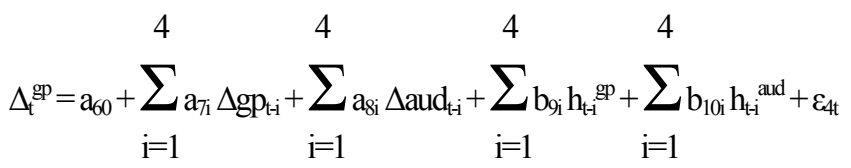

where $\Delta$ is the first-difference operator and $\varepsilon$ s are serially uncorrelated error terms. From the above equations, causality is determined by the statistical significance of the partial Fstatistic associated with the corresponding right-hand side variables. The results of the causality tests (with the signs in parentheses denoting the type of association) yield:

Equation $\Delta g p$

$$
\begin{array}{ll}
\Delta \text { aud } \rightarrow \Delta \mathrm{gp}(+) & \text { F-test }=57.89[\mathrm{p} \text {-value }=0.00] \\
\mathrm{h}^{\mathrm{gp}} \rightarrow \Delta \mathrm{gp}(-) & \text { F-test }=48.91[\mathrm{p} \text {-value }=0.00] \\
\mathrm{h}^{\mathrm{aud}} \rightarrow \Delta \mathrm{gp}(-) & \text { F-test }=56.16[\mathrm{p} \text {-value }=0.00]
\end{array}
$$

\section{Equation $\triangle$ aud}

$\Delta \mathrm{gp} \rightarrow \Delta$ aud(-)

F-test $=46.03[\mathrm{p}$-value $=0.00]$
$\mathrm{h}^{\mathrm{gp}} \rightarrow \Delta$ aud $(+)$
F-test $=41.38[p$-value $=0.00]$
$\mathrm{h}^{\text {aud }} \rightarrow \Delta \operatorname{aud}(+)$
F-test $=48.93[p$-value $=0.00]$

The results display that there is bidirectional causality between gold prices and the nominal exchange rate, yielding evidence against the assumption that gold prices are exogenous in a small open economy. At the same time, our results coincide with those reached by Blundell-Wignall and Gregory [12] and Gruen and Wilkinson [13], since causality is crucially dependent on the assumption that Australia is an international price-taker.

An alternative explanation for the causation running from the exchange rate to gold prices may be based on the 'incomplete exchange rate pass-through' hypothesis. The evidence on this hypothesis in Australia is mixed. The econometric evidence indicates that pass-through in import prices is complete and fairly rapid, while that in export prices is much slower (Dwyer et al. [28]; Dwyer and Lam [29]).

The presence of causality running from the nominal exchange rate to gold prices supports the view stressed in the literature of the association between asset and commodity markets, yielding that the exchange rate is a forward looking price which embodies information about future variables (Engel and West [30]; Bacchetta and van Wincoop [31]). Overall, the results provide empirical support to the association between the nominal exchange rate and its fundamentals.

Equation $h^{g p}$

$\begin{array}{ll}\Delta \mathrm{gp} \rightarrow \mathrm{h}^{\mathrm{gp}}(+) & \text { F-test }=39.18[\mathrm{p}-\text { value }=0.00] \\ \Delta \text { aud } \rightarrow \mathrm{h}^{\mathrm{gp}} & \text { F-test }=1.21[\mathrm{p} \text {-value }=0.19] \\ \mathrm{h}^{\text {aud }} \rightarrow \mathrm{h}^{\mathrm{gp}}(+) & \text { F-test }=37.62[\mathrm{p} \text {-value }=0.00] \\ \text { Equation } h^{\text {aud }} & \end{array}$

$\Delta \mathrm{gp} \rightarrow \mathrm{h}^{\text {aud }} \quad$ F-test $=1.24[\mathrm{p}$-value $=0.84]$

$\Delta$ aud $\rightarrow \mathrm{h}^{\text {aud }}(+) \quad$ F-test $=58.64[\mathrm{p}$-value $=0.00]$

$\mathrm{h}^{\mathrm{gp}} \rightarrow \mathrm{h}^{\mathrm{aud}}(+) \quad$ F-test $=45.11[\mathrm{p}$-value $=0.00]$

The empirical findings, in terms of conditional volatility, provide evidence against the exogenous price assumption for the case of a small open economy. In other words, there is evidence of bi-directional causality between the conditional volatility of gold prices and the corresponding volatility of the AU dollar/US dollar nominal exchange rate.

\section{ROBUSTNESS TESTS: THE REAL EXCHANGE RATE}

In the relevant literature, the fundamental approach to the determination and estimation of the equilibrium real exchange rate has been criticized on the grounds that attempts to model long-run movements in real exchange rates have generally generated mixed results. In particular, Edison and Melick [32] fail to find the presence of a longrun relationship between real exchange rates and real interest rate differentials, while Cashin et al. [33] argue that the PPP hypothesis provides empirical results about a weak long-run 
real exchange rate model. The least controversial studies display that there is a relationship between the real exchange rate and a number of macroeconomic variables (Edwards [34]; Smith [35]; Chen and Rogoff [6]). Chen and Rogoff [6] recognize that if researchers could find a source of real shocks that is sufficiently volatile, they could resolve the puzzle of mixed results. Such real factors play a significant role in the determination of the real exchange rate through certain mechanisms, such as the Balassa-Samuelson effect (Choudhri and Khan [36]).

More importantly, for the case of an exporting country, the role of terms of trade is exceptionally high. In this case, real exchange rate policies should be directed to align the real exchange rate with its fundamental determinants and, in our case, with changes in gold prices. Chen and Rogoff [6] focus on three 'commodity currencies' issued by large advanced countries, Australia, Canada and New Zealand. They find that commodity prices have a strong effect on their real exchange rates, especially in Australia and New Zealand. Cashin et al. [33] find that commodity terms of trade affect the real exchange rate, while Ricci et al. [11] estimate a panel cointegration relationship between certain fundamentals and real exchange rates in a sample of 48 countries.

\subsection{Modeling a Mean Process for the AU Dollar/US Dollar Real Exchange Rate}

The analysis identifies the appropriate AU dollar/US dollar real exchange rate process and is based on a version of the model estimated by Gruen and Wilkinson [13]. In particular, for a small, commodity-exporting country like Australia, changes in the terms of trade reflect changes in international commodity prices and have a direct impact on net exports and hence on the current account of the balance of payments. An unexpected deterioration in the terms of trade worsens the current account deficit. The unexpected increase in the current account deficit leads, in turn, to a real depreciation in the exchange rate.

Moreover, an additional role is also given to interest rate differentials (ri) in the relationship under examination. Therefore, we employ long-term real interest rate differentials as an indicator of the anticipated stance of Australian monetary policy relative to that in the US. An increase in the long-term real interest rate differentials favoring Australia would indicate a relative easing of monetary policy in Australia. We should expect this to lead to a real depreciation of the AU dollar.

After identifying the presence or not of unit roots in the new variables (Table 1), the AU dollar/US dollar real exchange rate is well described by the following Vector Autoregressive (VAR) model equation (the absence of a uniform unit root pattern prevents the presence of cointegration):

$$
\Delta \operatorname{rer}_{\mathrm{t}}=\mathrm{a}_{70}+\sum_{\mathrm{i}=1}^{3} \mathrm{f}_{\mathrm{fi}} \Delta \operatorname{rer}_{\mathrm{t}-\mathrm{i}}+\sum_{\mathrm{i}=1}^{3} \mathrm{f}_{2 \mathrm{i}} \Delta \mathrm{tt}_{\mathrm{t}-\mathrm{i}}+\sum_{\mathrm{i}=1}^{3} \mathrm{f}_{3 \mathrm{i}} \Delta \mathrm{dri}_{\mathrm{t}-\mathrm{i}}+\sum_{\mathrm{i}=1}^{3} \mathrm{f}_{4 \mathrm{i}} \Delta \mathrm{gp}_{\mathrm{t} \mathrm{i}-\mathrm{t}}+\theta_{\mathrm{t}}
$$

with $\theta_{\mathrm{t}}$ being the error term. Next, the $\Delta \mathrm{gp}$ and $\Delta$ rer equations form a 4 -variable equation system, i.e. $\Delta$ rer, $\Delta \mathrm{gp}$, $\Delta \mathrm{tt}$ and $\Delta \mathrm{dri}$, and the results are reported in Table 5 (we focus only on equations $\Delta \mathrm{gp}$ and $\Delta \mathrm{rer}$, while the remaining results are available upon request). Changes in real interest rates lead to changes in the demand for or the supply of commodities either through changing the incentive for extraction today rather than tomorrow or through changing a firm's desire to carry inventories or, finally, by encouraging speculators to shift out or into commodity contracts and bonds. We may call it part of the 'carry trade' process.

Table 5. VAR Model Estimates

\begin{tabular}{|c|c|c|}
\hline Coefficient & Gold Prices & $\begin{array}{l}\text { AU Dollar/US } \\
\text { Dollar Real Exchange Rate }\end{array}$ \\
\hline constant & $0.021(0.81)$ & \\
\hline$\Delta \mathrm{rer}_{-1}$ & $0.423(6.12)^{*}$ & \\
\hline$\Delta$ rer $_{-2}$ & $0.228(4.77)^{*}$ & \\
\hline$\Delta \mathrm{rer}_{-3}$ & $0.174(5.26)^{*}$ & \\
\hline$\Delta \mathrm{tt}_{-1}$ & $0.507(6.36)^{*}$ & \\
\hline$\Delta \mathrm{tt}_{-2}$ & $0.348(5.18)^{*}$ & \\
\hline dri $_{-1}$ & $0.129(4.81)^{*}$ & \\
\hline dri $_{-2}$ & $0.072(4.52)^{*}$ & \\
\hline$\Delta \mathrm{gp}_{-1}$ & $0.233(5.75)^{*}$ & \\
\hline$\Delta \mathrm{gp}_{-3}$ & $0.158(4.50)^{*}$ & \\
\hline constant & & $0.030(1.22)$ \\
\hline$\Delta \mathrm{gp}_{-1}$ & & $-0.485(5.86)^{*}$ \\
\hline$\Delta \mathrm{gp}_{-2}$ & & $-0.326(5.12)^{*}$ \\
\hline$\Delta \mathrm{rer}_{-1}$ & & $0.255(4.60)^{*}$ \\
\hline$\Delta \mathrm{tt}_{-1}$ & & $-0.428(5.77)^{*}$ \\
\hline$\Delta \mathrm{tt}_{-2}$ & & $-0.352(5.26)^{*}$ \\
\hline$\Delta \mathrm{tt}_{-3}$ & & $-0.258(4.92)^{*}$ \\
\hline dri $_{-1}$ & & $-0.261(-5.24)^{*}$ \\
\hline \multicolumn{3}{|c|}{ Diagnostic Statistics } \\
\hline $\mathrm{R}^{2}$ & 0.59 & 0.58 \\
\hline LM & $2.02[0.24]$ & $2.42[0.32]$ \\
\hline RESET & $1.17[0.22]$ & $1.55[0.53]$ \\
\hline $\mathrm{ARCH}(1)$ & $7.06[0.00]$ & $7.65[0.00]$ \\
\hline $\mathrm{ARCH}(4)$ & $7.29[0.00]$ & $6.49[0.00]$ \\
\hline $\mathrm{ARCH}(8)$ & $6.92[0.00]$ & $5.92[0.00]$ \\
\hline $\mathrm{ARCH}(12)$ & $6.54[0.00]$ & $6.27[0.00]$ \\
\hline
\end{tabular}

Once again, only the statistical significant variables are reported. Looking at the model's overall performance, the estimated equations satisfy certain econometric criteria, namely, absence of serial correlation (LM test) and absence of functional misspecification (RESET test). Finally, ARCH 
tests results reject the hypothesis of independent errors in both equations.

The above results denote that real shocks determine the behavior of the real exchange rate in the short-run, implying that Australia can have either a flexible nominal exchange rate regime or can facilitate slow changes of relative inflation rates or price and wage flexibility, or, finally, the maintenance of a nominal exchange rate peg system.

\subsection{Conditional Volatility Estimates: Spillovers Between Gold Prices Volatility and the AU Dollar/US Dollar Real Exchange Rate Volatility}

Once again, a GARCH model is considered as a parsimonious special case of an ARMA process applied to the squared stochastic error term. A Box-Jenkins selection procedure indicated that a $\operatorname{GARCH}(1,1)$ model exhibits the best fit. In this new case, a 4-conditional variance equation system is followed, with variables, such as the gold prices, the AU dollar/US dollar real exchange rate, the terms of trade, and the long-term real interest rates differential. The empirical results on conditional estimates for the variables under consideration are reported in Table 6. We report only those findings related to our focused variables, i.e. the real exchange rate and gold prices. Once again, numbers in parentheses are robust t-statistics.

The new empirical findings show that the estimates for the lagged variance terms are statistically significant in both equations at 1 per cent. The off-diagonal parameter $d_{\text {hgp,hrer }}$ is shown to be statistically significant at 1 per cent, indicating the gold prices-AU dollar/US dollar real exchange rate volatility trade-off. The parameters $\mathrm{d}_{\mathrm{gp}}$ and $\mathrm{d}_{\mathrm{rer}}$ are statistically significant at 1 per cent, lending support to the presence of a cross-effect. The parameters $d_{\text {hrer }}$ and $d_{\text {hgp }}$ show that the lagged exchange rate conditional variance raises gold prices conditional volatility. In other words, the conditional volatility of the real exchange rate factor is a good predictor for gold prices. Once again, such empirical findings provide support to the Meese-Rogoff [2] literature about the capacity of the exchange rate volatility to explain future movements in the commodity price volatility.

\subsection{Causality Effects}

Finally, to examine causal relationships among the variables under study, an $8 \times 8$ (the above four variables, i.e. the real exchange rate, gold prices, terms of trade, and real interest rate differentials plus their conditional variances) VAR model is estimated. The results of the causality tests yield:

\section{Equation $\Delta g p$}

$$
\begin{array}{ll}
\Delta \text { rer } \rightarrow \Delta \mathrm{gp}(+) & \text { F-test }=68.21[\mathrm{p} \text {-value }=0.00] \\
\mathrm{h}^{\mathrm{gp}} \rightarrow \Delta \mathrm{gp}(-) & \text { F-test }=51.28[\mathrm{p} \text {-value }=0.00] \\
\mathrm{h}^{\text {rer } \rightarrow \Delta \mathrm{gp}(-)} & \text { F-test }=67.81[\mathrm{p} \text {-value }=0.00]
\end{array}
$$

Equation Arer

$$
\Delta \mathrm{gp} \rightarrow \Delta \operatorname{rer}(-)
$$$$
\text { F-test }=57.90[\mathrm{p} \text {-value }=0.00]
$$$$
\mathrm{h}^{\mathrm{gp}} \rightarrow \Delta \operatorname{rer}(+)
$$$$
\text { F-test }=50.36[\mathrm{p} \text {-value }=0.00]
$$

$\mathrm{h}^{\mathrm{rer}} \rightarrow \Delta \mathrm{rer}(+)$

$$
\text { F-test }=48.49[\mathrm{p} \text {-value }=0.00]
$$

The results show that the presence of a bidirectional causality between gold prices and the real exchange rate

yields evidence that these prices are a forecasting determinant for the path of the real exchange rate. In addition, the presence of causality running from the real exchange rate to gold prices supports the view stressed in the literature of the association between asset and commodity markets, i.e. real exchange rates are also forward looking prices, which embodies information about future variables. Finally, the negative causality impact of gold prices on the real exchange rate implies that rising gold prices represent an improvement in the country's terms of trade, which supports a real appreciation effect. In other words, higher gold prices

\begin{tabular}{|c|c|c|}
\hline $\mathrm{d}_{\mathrm{hgp}}$ & \multicolumn{2}{|c|}{$0.493(6.36)^{*}$} \\
\hline$d_{\text {hrer }}$ & \multicolumn{2}{|c|}{$0.295(5.48)^{*}$} \\
\hline $\mathrm{d}_{\text {hgp,hrer }}$ & \multicolumn{2}{|c|}{$0.171(5.63)^{*}$} \\
\hline$d_{\text {ugp }}$ & \multicolumn{2}{|c|}{$0.240(5.47)^{*}$} \\
\hline $\mathrm{d}_{\text {urer }}$ & \multicolumn{2}{|c|}{$0.186(5.18)^{*}$} \\
\hline $\mathrm{d}_{\text {ugp, urer }}$ & \multicolumn{2}{|c|}{$0.094(6.11)^{*}$} \\
\hline $\mathrm{d}_{\text {hrer }}$ & \multicolumn{2}{|c|}{$0.162(5.07)^{*}$} \\
\hline$d_{\text {hgp }}$ & \multicolumn{2}{|c|}{$0.214(4.86)^{*}$} \\
\hline $\mathrm{d}_{\text {hrer,hgp }}$ & \multicolumn{2}{|c|}{$0.174(6.19)^{*}$} \\
\hline \multicolumn{3}{|c|}{ Diagnostic Statistics } \\
\hline $\mathrm{L}(\mathrm{Q})$ & \multicolumn{2}{|c|}{3972.38} \\
\hline $\mathrm{LM}_{1}$ & \multicolumn{2}{|c|}{$1.41[0.25]$} \\
\hline $\mathrm{LM}_{2}$ & \multicolumn{2}{|c|}{$1.25[0.40]$} \\
\hline \multirow[t]{2}{*}{$\mathrm{LM}_{3}$} & \multicolumn{2}{|c|}{$1.90[0.31]$} \\
\hline & $\Delta \mathbf{g p}$ & $\Delta$ rer \\
\hline $\mathrm{Q}(1)$ & $1.15[0.50]$ & $0.95[0.59]$ \\
\hline $\mathrm{Q}(4)$ & $1.44[0.42]$ & $1.34[0.56]$ \\
\hline$Q^{2}(1)$ & $1.84[0.31]$ & $1.71[0.35]$ \\
\hline$Q^{2}(4)$ & $1.20[0.47]$ & $1.70[0.33]$ \\
\hline $\mathrm{TR}^{2}$ & $1.67[0.37]$ & $1.29[0.39]$ \\
\hline \multicolumn{3}{|c|}{ Bollerslev's LM Test } \\
\hline $0.56[0.29]$ & $0.42[0.31]$ & \\
\hline
\end{tabular}
will improve Australia's terms of trade, they will boost export income and will generate a trade surplus, thus, stimulating the foreign demand for AUD, while they will cause an appreciation of the currency, leading to a deflationary effect in the real sector.

Table 6. Conditional Volatility Estimates: The 6-Variable Equation System 


\section{Equation $h^{g p}$}

$$
\begin{array}{ll}
\Delta \mathrm{gp} \rightarrow \mathrm{h}^{\mathrm{gp}}(+) & \text { F-test }=39.06[\mathrm{p} \text {-value }=0.00] \\
\Delta \mathrm{rer} \rightarrow \mathrm{h}^{\mathrm{gp}} & \text { F-test }=1.13[\mathrm{p} \text {-value }=0.22] \\
\mathrm{h}^{\mathrm{rer}} \rightarrow \mathrm{h}^{\mathrm{gp}}(+) & \text { F-test }=40.15[\mathrm{p} \text {-value }=0.00]
\end{array}
$$

\section{Equation $h^{\text {aud }}$}

$$
\begin{array}{ll}
\Delta \mathrm{gp} \rightarrow \mathrm{h}^{\text {rer }} & \text { F-test }=1.25[\mathrm{p}-\text { value }=0.78] \\
\Delta \mathrm{rer} \rightarrow \mathrm{h}^{\text {rer }}(+) & \text { F-test }=54.29[\mathrm{p} \text {-value }=0.00] \\
\mathrm{h}^{\mathrm{gp}} \rightarrow \mathrm{h}^{\text {rer }}(+) & \text { F-test }=41.55[\mathrm{p} \text {-value }=0.00]
\end{array}
$$

The empirical findings provide evidence that there is a bi-directional causality between the conditional volatility of gold prices and the corresponding volatility of the AU dollar/US dollar real exchange rate.

\section{CONCLUSIONS}

This paper provided evidence in favor of a relationship between the nominal/real exchange rate of the Australian dollar vis-à-vis the US dollar and gold prices, with daily data both in terms of means and conditional volatilities. The results are extremely important, in terms of information availability, for gold exporters, monetary policymakers, hedge funds managers and international portfolio managers. Causality estimations, both in means and in volatilities, revealed the presence of a bi-directional causality, which provides additional support to the hypothesis that both markets are driven by the same information set. In addition, the findings uncovered that exchange rates can be used to forecast future gold prices. In particular, the exchange rate between the Australian dollar and the US dollar offers an ideal reference point for extending the work on exchange rate asset pricing models.

Our empirical results have substantial implications for Australia, given the 'PEP' hypothesis. Although gold is not the only important exporting commodity of the country, a novel strategy would be for the monetary authorities to peg the AUD to a basket of commodity prices, including gold prices, at the cost of giving up the benefits of their discretionary monetary policy, which for the size of the country could not be an acceptable policy. At the same time, the automatic adjustment to terms of trade shocks could be highly beneficial not only to the reduction of risk and transaction costs in the production process, but also for the international competitiveness of the country, especially in periods where the balance of payments is under strong strain.

Future research efforts could proceed in certain directions. For instance, a future empirical effort on a panel basis, i.e. with more countries characterized as gold exporters, could give a better perspective on the results that incorporate (panel) cointegration and (panel) error correction. Finally, given the growing importance of China as a major consumer of Australian resource-based exports (e.g. on October 18, 2012, it was reported that gold in Australia had not only become Australia's second most important export to China-in value terms-but also that China's demand for gold now rivaled India's. With China being both Australia's largest trading partner and an increasing important player in world commodity markets generally, it is worth investigating whether the presence of a 'China effect' has simultaneously boosted the value of the Australian dollar and gold prices. This 'China effect' could be a crucial determinant for Australia's terms of trade, for domestic industrial production, and, thus, for the country's real exchange rate.

\section{CONFLICT OF INTEREST}

The authors confirm that this article content has no conflicts of interest.

\section{ACKNOWLEDGEMENTS}

The authors wish to express their gratitude to the Editor as well as to two referees for their helpful comments on an earlier draft. Needless to say, the usual disclaimer applies.

\section{REFERENCES}

[1] Sercu, P, Uppal R. Exchange rate determination. Int Finan Mark Firm. London: Chapman and Hall 1995.

[2] Meese R, Rogoff S. Exchange rate models of the seventies: do they fit out of sample? J Int Econ 1983; 14: 3-24.

[3] Frankel J, Rose A. A panel project on purchasing power parity: mean reversion within and between countries. J Int Econ 1995; 40: 209-24.

[4] Frankel JA. A proposed monetary regime for small commodity exporters: peg the export price ('PEP'). Int Finan 6: 61-88.

[5] Frankel JA, Saiki A. A proposal to anchor monetary policy by the price of the export commodity. J Econ Integ 2002; 17: 417-48.

[6] Chen Y, Rogoff K. Commodity currencies. J Int Econ 2003; 60: 133-60.

[7] Chen S. Real exchange rate fluctuations and monetary shocks: a revisit. Int J Finan Econ 2004; 9: 25-32.

[8] Chen Y, Rogoff K, Rossi B. Can exchange rates forecast commodity prices? Massachusetts: National Bureau Econ Res 2008; p. 13901.

[9] Cashin P, Cespedes LF, Sahay R. Commodity currencies and the real exchange rate. J Develop Econ 2004; 75: 239-68.

[10] Isard P. Equilibrium exchange rates: assessment methodologies. Washington: Int Monetary Fund 2007; 07/296.

[11] Ricci LA, Milesi-Ferretti JM, Lee J. Real exchange rates andfundamentals: a cross-country/perspective. Washington: Int Monetary Fund 2008; 08/013.

[12] Blundell-Wignall A, Gregory RG. Exchange rate policy in advanced commodity-exporting countries: the case of Australia and New Zealand. Paris: OECD Depart Econ Stat 1990; 83/1990.

[13] Gruen DWR, Wilkinson J. Australia's real exchange rate: is it explained by the terms of trade or by real interest rate differentials? Econ Record 1994; 70: 204-19.

[14] Blundell-Wignall A, Fahrer J, Heath R. Major influences on the Australian dollar exchange rate. In: Blundell-Wignall A, Eds. The exchange rate, international trade and the balance of payments. Sydney: Reserve Bank of Australia 1993.

[15] Baur DG, Lucey BM. Is gold a hedge or a safe haven? An analysis of stocks, bonds and gold. The Finan Rev 2007; 45: 217-29.

[16] Baryshevsky DV. The interrelation of the long-term gold yield with the yields of another asset classes. Finan Anal Group 2004. Available from: http://ssrn.com/abstract $=652441$

[17] Capie F, Mills TC, Wood G. Gold as a hedge against the dollar. J Int Finan Mark Inst Money 2005; 15: 343-52.

[18] Brischetto A, Voss G. A structural vector autoregressive model of monetary policy in Australia. Res bank Australia 1999; 1999-11.

[19] Dungey M, Pagan A. A structural VAR model of the Australian economy. Econ Rec 2000; 76: 321-42.

[20] Dickey DA, Fuller WA. Likelihood ratio statistics for autoregressive time series with a unit root. Economet 1981; 49: 1057-72. 
[21] Kwiatkowski D, Phillips P, Schmidt P, Shin Y. Testing the null hypothesis of stationary against the alternative of a unit root: how sure are we that economic time series have a unit root? J Economet 1992; 54: 159-78.

[22] Johansen S, Juselius C. Maximum likelihood estimation and inference on cointegration-with applications to the demand for money. Oxford Bulletin Econ Stat 1990; 52: 169-210.

[23] Sims CA. Macroeconomics and reality. Economet 1980, 48: 1-48.

[24] Engle RF, Kroner KF. Multivariate simultaneous generalized ARCH. Economet Theory 1995; 11: 122-50.

[25] Lee J. The inflation and output variability tradeoff: evidence from a GARCH model. Econ Lett 1999; 62: 63-7.

[26] Bollerslev T, Wooldridge JM. Quasi-maximum likelihood estimation and inference in dynamic models with time-varying covariances. Economet Rev 1992; 11: 143-72.

[27] Bollerslev T. On the correlation structure of the generalized autoregressive conditional heteroskedastic process. J Time Series Anal 1988; 9: 121-31

[28] Dwyer J, Kent C, Pease A. Exchange rate pass-through: testing the small country assumption. Econ Rec 1994; 70: 408-23.
[29] Dwyer J, Lam R. The two stages of exchange rate pass-through: implications for inflation. Aust Econ Papers 1995; 34, 157-79.

[30] Engel C, West KD. Exchange rates and fundamentals. J Polit Econ 2005; 113: 485-517.

[31] Bacchetta P, van Wincoop E. Can information heterogeneity explain the exchange rate determination puzzle? Am Econ Rev 2006; 96: 555-76.

[32] Edison H, Melick W. Alternative approaches to real exchange rates and real interest rates: three up and three down. Int J Finan Econ 1999; 4, 93-111.

[33] Cashin P, Felipe I, Sahay C. Commodity currencies and the real exchange rates. Central Bank of Chile 2003; 236.

[34] Edwards S. Exchange rate misalignment in developing countries World Bank Research Observer 1989; 4, 3-21.

[35] Smith CE. Exchange rate variation, commodity price variation and the implications for international trade. J Int Money Finan 1999; 18: 471-91.

[36] Choudhri EU, Khan MS. Real exchange rates in developing countries: are Balassa-Samuelson effects present? Washington: Int Monetary Fund 2004; 04/188.

(C) Apergis and Papoulakos; Licensee Bentham Open.

This is an open access article licensed under the terms of the Creative Commons Attribution Non-Commercial License (http://creativecommons.org/licenses/bync/3.0/) which permits unrestricted, non-commercial use, distribution and reproduction in any medium, provided the work is properly cited. 